\title{
IMUNIDADE TRIBUTÁRIA DAS INSTITUIÇÕES RELIGIOSAS
}

\author{
TAX IMMUNITY OF RELIGIOUS INSTITUTIONS
}

RESUMO: Este artigo examina o instituto do direito fundamental da imunidade tributária das instituições religiosas, disciplinado pela Constituição brasileira, através tanto de sua análise teórica, como pelo estudo de casos práticos submetidos à interpretação judicial, a fim de propiciar ao leitor critérios para a correta aplicação desse direito, que se presta a facilitar o exercício de outro direito fundamental, que é o direito à liberdade religiosa.

PALAVRAS-CHAVES: Imunidade tributária. Liberdade religiosa. Interpretação.

ABSTRACT: This article examines the institute of the fundamental right of tax immunity of religious institutions, disciplined by the Brazilian Constitution, through both its theoretical analysis and the study of practical cases submitted to judicial interpretation, in order to provide the reader with criteria for the correct application of this right, which lends itself to facilitating the exercise of another fundamental right, which is the right to religious freedom.

KEYWORDS: Tax Immunity. Religious Freedom. Interpretation.

1 Professor da UNEB - Universidade do Estado da Bahia, Campus XIX - Camaçari. Doutor e Mestre em Direito Público pela UFBA - Universidade Federal da Bahia. Leciona Direito Tributário, Direito Internacional e Direito Constitucional. 


\section{INTRODUÇÃO}

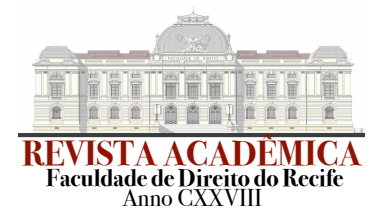

O presente trabalho trata do direito das instituições religiosas à imunidade tributária como um importante instrumento para uma maior efetivação do direito à liberdade religiosa. Primeiramente, será feita uma análise do instituto conforme sua disciplina constitucional, e se esta configura um privilégio ou, ao contrário, uma garantia contra possíveis discriminações.

Após esta etapa, o presente trabalho destacará importantes decisões da jurisprudência, em especial dos tribunais superiores, em que se discutiu amplamente a imunidade constitucional referida, e como a interpretação da norma constitucional, na esmagadora maioria dos casos, tem sido feita de forma a conferir a maior eficácia possível ao direito individual de não incidência tributária de caráter qualificado, eis que previsto na Carta Maior. O estudo destas fontes primárias de pesquisa permitirá um estudo que ultrapasse os delineamentos teóricos, pois se verá como os casos práticos têm sido trabalhados.

Para enriquecimento da análise prática, será também estudado julgado em meados de 2011 pela Corte Europeia dos Direitos Humanos, em que se analisou se o Estado francês teria o direito de tributar associação religiosa e se tal imposição de exação combinada com multa fiscal contra tal associação guardaria caráter nitidamente discriminatório.

O trabalho se serviu de fontes bibliográficas e de casos judiciais selecionados, com opção pelo método indutivo para a solução do problema proposto, que é o da discussão da legitimidade do direito à imunidade tributária como uma essencial ferramenta de proteção contra a discriminação religiosa, sem, contudo, abrir mão de uma abordagem sistemática na análise teórica do tema. Por fim, o estudo se justifica pela sua repercussão prática.

\section{SOBRE A IMUNIDADE DAS INSTITUIÇÕES E ATIVIDADES RELIGIOSAS AOS IMPOSTOS NO ORDENAMENTO JURÍDICO BRASILEIRO}

As imunidades não são novas. No Império Romano, havia o immunitas, que exonerava certas pessoas ou situações de serem tributados (incluindo templos religiosos e bens 


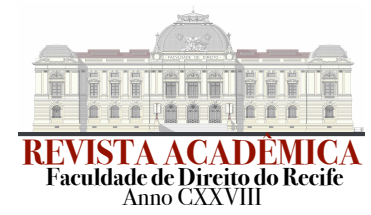

públicos). As imunidades já foram encaradas como privilégios - os nobres não pagavam tributos, bem como a Igreja, mas os pobres eram tributados. Com a vitória do liberalismo, as imunidades passaram a ter feição democrática e a representar garantias constitucionais (CARNEIRO, 2010, p. 325-327).

No patrimonialismo português, a imunidade tributária era um direito apenas da Igreja Católica, concedido pelo rei, uma limitação do poder do príncipe pela preexistente liberdade do estamento privilegiado. Com o advento do Estado independente brasileiro, a Constituição de 1824 tecnicamente suprimiu a imunidade, quando estabeleceu que "ninguém está isento de contribuir para as despesas do Estado em proporção de seus haveres" (artigo 179, item 15). Porém, foram muitas as leis concessivas de isenções para as mitras e os conventos. Mesmo após o Império, as leis de isenção, e não a proteção constitucional, ainda era a regra. Somente em 1946 que a imunidade foi constitucionalizada para todas as religiões, o que se repetiu nas Constituições seguintes (TORRES, 2005, p. 249 - 250), inclusive atualmente na Constituição Federal (CF) de 1988.

As imunidades tributárias são classificadas na atual Constituição como direitos individuais. Já que não se pode falar em crédito tributário inexistente (pois ou ele existe e tem validade ou de crédito não se tratará e nem haverá pretensão) (BORGES, 1999, p. 57), as hipóteses constitucionais de imunidade são aquelas em que simplesmente não há hipótese jurídica de incidência tributária.

As imunidades tributárias são direitos individuais que possuem aplicação imediata (por força do artigo $5^{\circ}, \S 1^{\circ}$, da $\mathrm{CF}$ ), são cláusulas pétreas (não podem ser abolidas por emenda constitucional) e possuem hierarquia constitucional (se alguma lei dificultar ou impedir desproporcionalmente sua aplicação poderá ser declarada inconstitucional).

Quanto ao aspecto formal, as imunidades inibem o exercício da competência tributária. A rigor elas não subtraem competência tributária, pois esta é apenas a soma das atribuições fiscais que a CF outorga ao poder tributante, enquanto que o campo material imune nunca pertence à competência do Estado, limitada pela Lei Maior (BORGES, 2001, p. 217). 


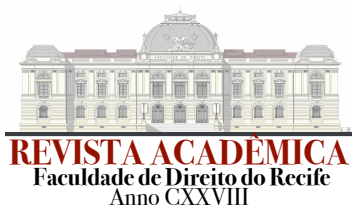

A regra de imunidade configura hipótese constitucional de não incidência qualificada e é negativa de competência. Diferente da isenção, ela não se caracteriza como regra excepcional frente ao princípio da generalidade do tributo. O poder que imuniza é erga omnes (contra todos) e sem limites de qualquer natureza (BORGES, 2001, p. 218- 219 e p. 221-222). Também é irrelevante a capacidade contributiva das pessoas beneficiadas pela imunidade, que não tem relação direta com o interesse de arrecadação tributária, pois sempre se caracteriza como proibição de tributar (MACHADO, 2003, p. 291).

A imunidade tributária das atividades religiosas se refere à não cobrança de impostos, mas é possível haver a cobrança de outros tipos de tributos, conforme o artigo 150, inciso VI, alínea $b$, da CF. porém, nada impede que Estados e Municípios criem isenções para taxas que beneficiem as mesmas instituições apontadas no dispositivo mencionado ("templos de qualquer culto"), mas tais isenções não serão cláusulas pétreas, podendo ser revogadas.

A palavra "templo" pode ser interpretada de forma ampla ou restrita. Na primeira, indica toda a ordem religiosa, incluindo a administração e o pessoal necessário ao funcionamento. Na segunda, somente o local de reunião. Do ponto de vista constitucional, a primeira acepção é a que melhor realiza o direito (ANDRADE FILHO, 2005, p. 117).

No caso dos templos, o que se procura proteger dos impostos não é apenas o edifício, mas as suas atividades. Não se tributam os rituais. Não se deve restringir a imunidade porque uma religião é parecida com outra. A imunidade se estende para anexos como um convento, residências para ministros religiosos, e estruturas utilizadas apenas para atividades religiosas, mesmo que sejam embarcações, veículos, vagões e aviões (BALEEIRO, 1997, p. 308, 311-312).

A imunidade tributária dos templos, portanto, visa proteger o cultivo dos valores espirituais, não apenas o prédio. Aponta a doutrina que a Constituição foi além ao se referir aos "templos de qualquer culto", pois uma celebração em homenagem a algo ou alguém, de expressão cultural, como o culto à memória, está abrangida pela imunidade, apesar da leitura rápida da Constituição remeter o pensamento para o culto religioso (KFOURI JR, 2010, p. 107). 


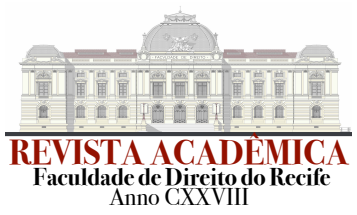

Também há que se pontuar que a finalidade essencial dos templos se se referem à existência e manutenção dos mesmos, e do exercício da religiosidade. Não se relaciona com atender a todas as necessidades sociais da sociedade. A imunidade dos templos não foi criada para promover a caridade, e sim, para promover a liberdade religiosa (VERGUEIRO, 2005, p. 161).

A imunidade dos templos, ao contrário de outras imunidades, não pode ser acompanhada de subvenções (auxílios como privilégios financeiros). A liberdade religiosa $\left(\mathrm{CF}\right.$, artigo $\left.5^{\circ}, \mathrm{VI}\right)$, fundamenta tal imunidade, pois tal liberdade é um atributo da própria pessoa humana e é condição de validade dos direitos fundamentais (TORRES, 2005, p. 251-252).

Assim, o titular da imunidade é a instituição religiosa, não apenas o templo. A lei também não define o que é religião, pois o conceito desta é aberto, o que implica que a interpretação do que venha a ser religião deve ser a mais ampla possível para não prejudicar as minorias. O controle administrativo ou judicial se restringe aos abusos e à simulação para obtenção de vantagem fiscal. Também a imunidade protege a propriedade privada, pois os impostos sobre o patrimônio e a renda têm grande potencial para sufocá-la (TORRES, 2005, p. 165 e 253$)$.

Entretanto, críticas há em relação à amplitude da garantia constitucional por conta da disputa por dinheiro entre algumas religiões que estariam ofendendo "princípios éticos" e também praticando "atos de mercancia", e, assim, não poderiam continuar à margem da tributação por ofensa ao princípio da isonomia tributária. Porém, ao se falar da imunidade dos livros, não importaria o conteúdo deles, pois tal imunidade seria objetiva (HARADA, 2004, p. 390 e 393).

Apesar de se fazer mau uso da religião para enriquecimento ilícito de alguns, não se pode presumir que todos o fazem, e também a imunidade tributária das instituições religiosas deve acompanhar o mesmo raciocínio da imunidade dos livros, ou seja, ela é para todos, não cabendo uma espécie de censura tributária à liberdade de pensamento e de palavra. 


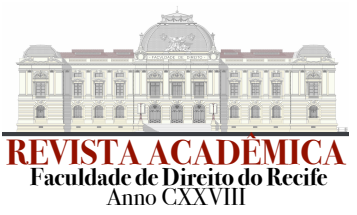

É necessária ainda uma interpretação extensiva da locução culto religioso. Por mais exóticas ou extravagantes que certas manifestações possam ser, todas merecerão ser consideradas templos (CARVALHO, 1999, p. 184). O que é extravagante para alguém não o é para outra pessoa. Todo sistema de crenças, não importa sua natureza, se possui ou não uma divindade, deverá ser protegido pela imunidade tributária aos templos.

As imunidades são normas negativas de incompetência que não podem ser restringidas ou anuladas nem por lei complementar. Portanto, possuem eficácia plena e aplicabilidade imediata, tornando inconstitucionais as manifestações interpretativas e os atos administrativos que as desafiam (CARRAZA, 2012, p. 2-3 e 6).

O fato da CF, no artigo 150, inciso VI, alínea $b$, ter usado o plural "templos", não torna a imunidade restrita aos edifícios religiosos. O benefício alcança a própria Organização religiosa. Assim, não incidirá o Imposto Predial e Territorial Urbano (IPTU) sobre o imóvel religioso, nem o Imposto sobre Serviços (ISS) sobre a prestação de serviço religioso, nem o Imposto sobre a Renda de Pessoa Jurídica (IRPJ) sobre os donativos feitos pelas pessoas, nem o Imposto sobre a Transmissão de Bens Imóveis (ITBI) na aquisição de bens imóveis por ato oneroso, nem o Imposto de Importação (II) na importação de bens relacionados à atividade religiosa, nem o Imposto sobre a Circulação de Mercadorias e Serviços (ICMS) ou o Imposto sobre Produtos Industrializados (IPI) sobre os livros, jornais e periódicos, inclusive em formato eletrônico, de caráter religioso, produtos também amparados pela alínea $d$ do mesmo dispositivo, e nem o Imposto sobre a Propriedade de Veículos Automotores (IPVA) sobre o veículo destinado à obra religiosa. Nenhum imposto, enfim, pode ser cobrado (CARRAZA, 2012, p. 11;13 e 22-23).

A CF, ao mencionar a expressão "finalidades essenciais" no artigo 150, § $4^{\circ}$, não leva em conta o modo como a instituição religiosa carreia recursos, mas sim, o lugar aonde tais recursos serão aplicados ou como serão usados. O que é preciso, então, é que fique evidente que os donativos estejam sendo direcionados à atividade religiosa. Esse entendimento é corroborado pela Súmula 724 do STF (embora esta faça alusão à alínea $c$ do inciso VI do artigo 150 da CF, é coerente para a situação da alínea b) (CARRAZA, 2012, p.18 e 20). 


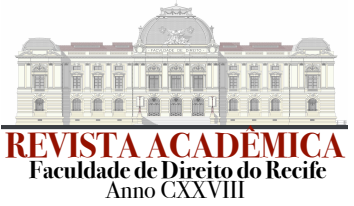

O que é, então, ter ânimo de lucro? Não é meramente obter rendas, mas também fazer a repartição delas. De modo técnico, o lucro objetivo (obtenção de renda), precisa ser diferenciado do lucro subjetivo (distribuição das rendas entre os dirigentes da instituição religiosa). O dinheiro precisa ser destinado à consecução dos objetivos religiosos (CARRAZA, 2012, p.23).

Os templos são imunes ao ISS porque é a imunização dos serviços prestados, e não apenas das edificações, que assegura o direito individual do livre exercício da religião. É preciso entender que também há a vedação da exigência do referido imposto de instituições mantenedoras de templos. Se os tributos atingem pessoas, as imunidades também visam proteger as pessoas, e não simplesmente os bens. Apesar de a CF, no artigo 150, VI, alíneas $b$ e $c$, não ter usado linguagem primorosa, o termo "entidade" aí referido não se aplica aos templos em si, mas às instituições que os mantêm, e também se protege as mesmas de impostos sobre o patrimônio, as rendas e os serviços relacionados. A imunidade aos impostos do livro, jornal, periódico, e do papel destinado à impressão de escritos religiosos também é garantida pela CF na alínea $d$ do dispositivo acima mencionado (BARRETO, 2009, p. 80-81 e 89).

A imunidade dos livros foi defendida por Jorge Amado na Constituinte de 1946. Seu interesse era cultural. O imposto encareceria o livro. O papel importado, se tributado fosse, encareceria o nacional. Tal imunidade é ampla, atingindo inclusive edições de luxo para colecionadores (BALEEIRO, 1997, p. 339 e 341), não importa se a edição tem ou não caráter religioso.

\section{ANÁLISE DE CASOS SELECIONADOS DA JURISPRUDÊNCIA BRASILEIRA}

Em julgado de 1953, o STF, por unanimidade, fez interpretação restritiva da imunidade aos templos. Só os imóveis que fossem estritamente utilizados para o "exercício do culto" é que eram protegidos (a "igreja”, o seu edifício, e suas dependências). Um lote isolado 




de terreno não era considerado como pertencendo ao edifício do templo. Tal entendimento perdurou por muito tempo². Já em Recurso Extraordinário (RE) com julgamento efetuado no final de 2002, o STF rompeu definitivamente com o precedente de 1953, já citado acima. Os imóveis alugados pertencentes à instituição religiosa também são imunes ao IPTU. A imunidade deve abranger também o patrimônio, a renda e os serviços relacionados com as finalidades essenciais das entidades religiosas, conforme o artigo $150, \S 4^{\circ}$, da $\mathrm{CF}$, que se aplica tanto à situação descrita na alínea $b$ como na alínea $c$ do inciso VI do mesmo artigo ${ }^{3}$.

Tal decisão reformou o acórdão prolatado pelo Tribunal de Justiça do Estado de São Paulo. Para o Município de Jales, "templo" é o local onde são feitas as celebrações religiosas e as dependências que servem diretamente aos seus fins. Para a Mitra Diocesana, os "centros pastorais ou de formação humano-religiosa, locais de reunião e administração, residências de padres e religiosos encarregados dos trabalhos da Igreja", além dos imóveis alugados para ajudar a garantir a "sustentação de sua missão" também devem ser imunes ao IPTU.

O Ministro Marco Aurélio de Mello, em seu voto, destacou a diferença entre subvenção, que é o aporte de recursos, e a imunidade, em que não há tal ato positivo. $\mathrm{O}$ Tribunal Pleno, por sete votos a quatro (vencidos os Ministros Ilmar Galvão - Relator, Ellen Gracie, Carlos Velloso e Sepúlveda Pertence), considerou imunes os imóveis de instituição religiosa que estejam alugados.

O STF também já considerou que os imóveis destinados à residência de ministros religiosos estão protegidos pela imunidade tributária, e invocou o precedente do $\mathrm{RE} \mathrm{n}^{\mathrm{o}}$ 325.822/SP e a Súmula $n^{\circ} 724$, que considerou imunes ao IPTU os imóveis alugados a

2 BRASIL. Supremo Tribunal Federal. Recurso Extraordinário no 21.826/DF. Relator: Min. A. M. Ribeiro da Costa. Julgamento: 02/07/1953. Publicado DJ 30/12/1953. Brasília: Supremo Tribunal Federal, 1953. Disponível em: <http://redir.stf.jus.br/paginadorpub/paginador.jsp?docTP=AC\&docID=123183> Acesso em: 19 jun. 2014.

3 BRASIL. Supremo Tribunal Federal. Recurso Extraordinário no 325.822-2/SP. Relator: Min. Ilmar Galvão. Relator para Acórdão: Min. Gilmar Mendes. Julgamento: 18/12/2002. Publicado DJ 15/05/2004. Brasília: Supremo Tribunal Federal, 2004. Disponível em: <http://redir.stf.jus.br/paginadorpub/paginador.jsp? docTP=AC\&docID=260872> Acesso em: 09 set. 2013. 


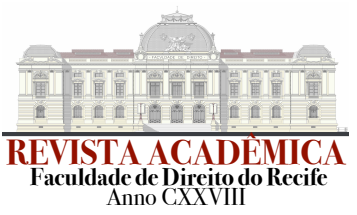

terceiros, mas pertencentes a uma instituição religiosa, desde que o valor dos aluguéis seja aplicado nas atividades essenciais da entidade. Desta feita, a decisão foi unânime ${ }^{4}$.

Outro caso paradigmático foi a decisão proferida pelo Supremo Tribunal Federal (STF) na Ação Direta de Inconstitucionalidade (ADI) n 939-7. Discutiu-se a respeito da criação do Imposto Provisório sobre Movimentações Financeiras (IPMF) através de emenda constitucional de 1993. O julgamento definitivo ocorreu em 15 de dezembro de 19935.

O STF, por maioria de votos, decidiu que uma emenda não pode violar o texto original da CF, como as cláusulas pétreas. A Emenda Constitucional (EC) $\mathrm{n}^{\mathrm{o}} 3$ foi considerada inconstitucional por restringir o alcance das imunidades tributárias. Em consequência, a Lei Complementar (LC) nº 77/1993 também foi declarada inconstitucional neste quesito.

Na mesma Ação, o Ministro Carlos Velloso entendeu que as imunidades não podem ser afetadas por EC. O Ministro Celso de Mello também criticou a interferência da EC tanto no afastamento do princípio da anterioridade quanto na restrição às imunidades, destacando o perigo de conceder ao poder de reforma constitucional a faculdade de, em desfavor do contribuinte, reduzir ou suprimir direitos individuais, ainda que temporariamente. As imunidades servem para bloquear o arbítrio do Estado e conferem efetividade a determinados direitos e garantias fundamentais assegurados a pessoas e instituições. E o Ministro Sepúlveda Pertence criticou a ocorrência de uma inaceitável censura tributária, via EC, à liberdade de natureza constitucional como é o caso da própria liberdade de manifestação do pensamento. Assim, ficou garantido pela interpretação do STF que as imunidades são cláusulas pétreas que não podem ser anuladas nem por EC nem por legislação infraconstitucional.

Em mais um caso, o STF decidiu, no Agravo Regimental no Recurso Extraordinário com Agravo $\mathrm{n}^{\mathrm{0}} 740.563 / \mathrm{SP}$, que o momento de aquisição do bem imóvel pela entidade assistencial ou religiosa é o termo inicial para o exercício do direito à imunidade tributária. É

\footnotetext{
4 BRASIL. Supremo Tribunal Federal. Agravo Regimental no Recurso Extraordinário com Agravo $\mathbf{n}^{\circ}$ 694.453/DF. Relator: Min. Ricardo Lewandowski. Julgamento: 25/06/2013. Publicado DJ ?/?/?. Brasília: Supremo Tribunal Federal, 2013. Disponível em: <http://redir.stf.jus.br/paginadorpub/paginador.jsp? docTP=TP\&docID=4307503> Acesso em: 09 set. 2013.
}

5 BRASIL. Supremo Tribunal Federal. Ação Direta de Inconstitucionalidade no 939-7/DF. Relator: Min. Sydnei Sanches. Julgamento: 15/12/1993. Publicado DJ 18/03/1994. Brasília: Supremo Tribunal Federal, 1994. Disponível em: <http://www.stf.jus.br> Acesso em 15 out. 2014. 


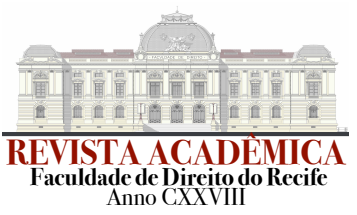

irrelevante que o imóvel esteja vago. Não há que se restringir a concessão do direito ao momento da aprovação de qualquer projeto, que pode inclusive sofrer atrasos desde a dificuldade financeira da instituição para a construção do templo até a lentidão burocrática do próprio Poder Público. Só a utilização diversa do imóvel para outros fins é que autoriza a não concessão da imunidade. Invocaram-se precedentes como o já referido RE $n^{\circ} 325.8226$.

Já no julgamento do RE $\mathrm{n}^{\mathrm{o}}$ 578.562-9/BA, o STF reformou a decisão do Tribunal de Justiça do Estado da Bahia, considerando que o Cemitério da Igreja de São Jorge e o Cemitério Britânico são merecedores da imunidade constitucional dos templos ao IPTU porque eles são extensões de entidades de cunho religioso. A imunidade tributária deve ser interpretada a partir da totalidade do texto constitucional, sobretudo os dispositivos do artigo $5^{\circ}$, inciso VI; do artigo 19, inciso I, e do artigo 150, inciso VI, alínea $b$. A decisão foi unânime, restaurando o entendimento da sentença de $1^{\circ} \operatorname{grau}^{7}$.

Também o STF, no RE no 225.778-9/SP, em votação unânime, decidiu que não se pode restringir a aplicação da imunidade através de critérios de classificação dos impostos adotados por normas infraconstitucionais. Não é adequado distinguir entre bens e patrimônio, pois este na verdade se constitui do conjunto daqueles. O que importa é se o bem adquirido, no mercado interno ou externo, integra o patrimônio da entidade abrangida pela imunidade. $\mathrm{O}$ caso concreto envolveu a compra de cabeças de gado para criação e consumo interno dos ministros religiosos residentes na sede da Associação Torre de Vigia (representante das Testemunhas de Jeová), e não para o comércio ${ }^{8}$.

O STF, no Agravo Regimental ao Agravo de Instrumento $n^{\circ} 740.563 / \mathrm{SP}$, decidiu que lei ordinária não pode criar hipótese de exclusão de imunidade. No caso concreto, a Lei $\mathrm{n}^{\mathrm{o}}$

\footnotetext{
6 BRASIL. Supremo Tribunal Federal. Agravo Regimental no Recurso Extraordinário com Agravo $\mathbf{n}^{\circ}$ 658.080/SP. Relator: Min. Luiz Fux. Julgamento: 13/12/2011. Publicado DJ 15/02/2012. Brasília: Supremo Tribunal Federal, 2012. Disponível em: <http://redir.stf.jus.br/paginadorpub/paginador.jsp? docTP=TP\&docID=1738528> Acesso em: 09 set. 2013.
}

${ }^{7}$ BRASIL. Supremo Tribunal Federal. Recurso Extraordinário no 578.562-9/BA. Relator: Min. Eros Grau. Julgamento: 21/05/2008. Publicado DJ 11/09/2008. Brasília: Supremo Tribunal Federal, 2008. Disponível em: $<$ http://redir.stf.jus.br/paginadorpub/paginador.jsp?docTP=AC\&docID=547393> Acesso em: 09 set. 2013.

8 BRASIL. Supremo Tribunal Federal. Agravo Regimental no Recurso Extraordinário no 225.778-9/SP. Relator: Min. Carlos Velloso. Julgamento: 16/09/2003. Publicado DJ 10/10/2003. Brasília: Supremo Tribunal Federal, 2003. Disponível em: <http://redir.stf.jus.br/paginadorpub/paginador.jsp?docTP=AC\&docID=332044> Acesso em: 09 set. 2013. 


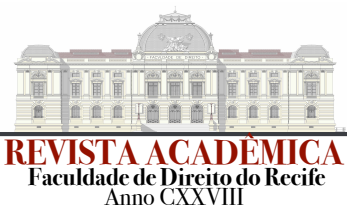

9.532/1997, no artigo $12, \S 1^{\circ}$, excluiu da imunidade os rendimentos e ganhos de capital auferidos em aplicações financeiras de renda fixa ou variável. O dispositivo legal ofendeu o artigo 146, II, da CF, que determina que as limitações ao poder de tributar sejam reguladas por lei complementar. Também a imposição tributária atingiu o patrimônio da entidade (“Fundação Padre Albino”), o que é vedado pela CF, pois as aplicações financeiras visam resguardar o patrimônio dos efeitos corrosivos da inflação, e não para auferir lucros. Por fim, o dispositivo legal teve sua vigência suspensa por força de decisão proferida em Medida Cautelar na ADI n 1802 . A decisão foi unânime9 .

No Agravo Regimental ao Agravo de Instrumento $\mathrm{n}^{\circ}$ 805.722/SP, o STF também discutiu a mesma matéria do anterior, mas aqui se acrescentou que não se justifica a suspensão de ações individuais em que se postula o reconhecimento da não tributação da renda auferida por sujeitos imunes em aplicações financeiras, bem como a repetição do indébito. Também foi destacado que a jurisprudência do STF é firme no sentido de que as entidades de assistência social, sem fins lucrativos, estão imunes à incidência do imposto de renda (neste caso, a entidade foi a Sociedade Hebraico-Brasileira Renascença) ${ }^{10}$.

O Conselho Administrativo de Recursos Fiscais (CARF), por sua $3^{\text {a }}$ Seção de Julgamento, decidiu que a imunidade da Contribuição para o Financiamento da Seguridade Social (COFINS) dos templos de qualquer culto está condicionada ao cumprimento dos requisitos legais. Porém, considerou que a receita oriunda da revenda de Bíblias, livros religiosos, CDs, DVDs, terços e demais produtos de cunho religioso não devem ser tributados, pois, no caso, se referiam ao objetivo de difusão da religião Católica, e eram distribuídos através da Associação do Senhor Jesus, cujo Estatuto não tinha qualquer conotação empresarial e nem finalidade lucrativa. Foi decidido que uma Instrução Normativa não pode determinar o alcance semântico de atividades que a legislação não estabeleceu com

9 BRASIL. Supremo Tribunal Federal. Agravo Regimental no Agravo de Instrumento $\mathbf{n}^{\mathbf{0}} \mathbf{7 4 0 . 5 6 3 / S P}$. Relator: Min. Luiz Fux. Julgamento: 02/04/2013. Publicado DJ ?/?/?. Brasília: Supremo Tribunal Federal, 2013. Disponível em: <http://redir.stf.jus.br/paginadorpub/paginador.jsp?docTP=TP\&docID=3688046> Acesso em: 09 set. 2013.

10 BRASIL. Supremo Tribunal Federal. Agravo Regimental no Agravo de Instrumento $\mathbf{n}^{\mathbf{0}}$ 805.722/SP. Relator: Min. Rosa Weber. Julgamento: 26/02/2013. Publicado DJ ?/?/?. Brasília: Supremo Tribunal Federal, 2013. Disponível em: <http://redir.stf.jus.br/paginadorpub/paginador.jsp?docTP=TP\&docID=3495941 $>$ Acesso em: 09 set. 2013. 


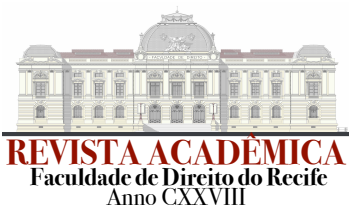

fins de restrição da isenção/imunidade ou criar condicionamentos para o gozo dos mesmos. $\mathrm{O}$ CARF, nesta decisão, só não aceitou a imunidade em relação à veiculação de patrocínios, como anúncios na televisão e em revista, por não se destinarem à difusão da religião ${ }^{11}$.

Já em decisão proferida no RE no 221.395-8/SP, o STF concluiu que os imóveis pertencentes à instituição religiosa de educação e de assistência social sem fins lucrativos, que estejam servindo de escritório e moradia de seus membros, além de servirem como depósito de materiais utilizados pela entidade em suas atividades, estão protegidos pela imunidade prevista pelo artigo 150, VI, $c$, e $\S 4^{\circ}$, da CF. O Relator foi o Ministro Marco Aurélio de Mello. A decisão foi unânime, modificando decisão do Tribunal de Justiça de São Paulo ${ }^{12}$.

O recorrente foi a Sociedade (hoje Associação) Torre de Vigia de Bíblias e Tratados (representante das Testemunhas de Jeová) e o recorrido foi o Município de São Paulo. O objetivo da Associação é o de ensinar, preparar e equipar homens e mulheres a servirem como ministros e instrutores religiosos, deixando com as pessoas suas publicações religiosas, e as convidando a participar de estudos bíblicos gratuitos, além de supervisionar escolas gratuitas de alfabetização, cujo trabalho é estendido aos lares das pessoas interessadas e manter cursos e classes para instrução gratuita da Bíblia. Também se provê alojamento gratuito de ministros que estejam envolvidos neste serviço, além de apoio às vítimas de calamidades públicas e catástrofes naturais. Foi pontuado que não é necessário que esteja acontecendo um curso no imóvel, basta que ele esteja em prol da atividade educativa para ser imune ao IPTU.

O Ministro Néri da Silveira, em voto separado, destacou que a imunidade protege toda a infraestrutura erguida e preparada para a atividade da instituição. Também em voto separado, o Ministro Celso de Mello chamou à atenção que a imunidade em questão representa uma expressiva garantia constitucional que, no âmbito do Estado laico, impede que o Poder Público pratique “inaceitável censura tributária sobre atividades confessionais de uma

11 BRASIL. Ministério da Fazenda - Câmara Superior de Recursos Fiscais. Processo no 10830.004351/2008-36. Relatora: Ana Clarissa Masuko dos Santos Araújo. Julgamento: 24/10/2013. Brasília: Câmara Superior de Recursos Fiscais, 2013. Disponível em: <http://www.carf.fazenda.gov.br> Acesso em 09 fev. 2015.

12 BRASIL. Supremo Tribunal Federal. Recurso Extraordinário no 221.395-8/SP. Relator: Min. Marco Aurélio. Julgamento: 08/02/2000. Publicado DJ 12/05/2000. Brasília: Supremo Tribunal Federal, 2000. Disponível em: $<$ http://redir.stf.jus.br/paginadorpub/paginador.jsp?docTP=AC\&docID=249570 $>$ Acesso em: 09 set. 2013. 


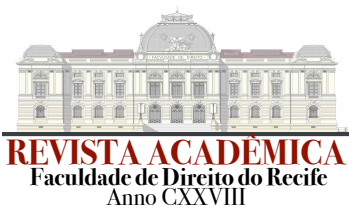

instituição claramente comprometida com a difusão de determinada fé religiosa". Os imóveis em questão estavam inequivocamente destinados às finalidades essenciais da Recorrente.

Este caso deixou claro que há instituições de educação e assistência que, tendo em vista suas finalidades, também devem ser vistas como verdadeiros templos em sentido antropológico, pois são consideradas sagradas e destinadas à prática da fé. Este artigo defende que tais instituições se enquadrem nas alíneas $b$ e $c$ do inciso VI, do artigo 150 da CF.

Na decisão do Agravo Regimental no Agravo de Instrumento no $378.454-2 / \mathrm{SP}$, o STF, considerou que a imunidade prevista no artigo 150, VI, $c$, da CF, abrange o II e o IPI, que incidiriam sobre bens a serem utilizados nas prestações de seus serviços específicos. A agravante, que foi a União, alegou que a imunidade prevista só se aplicaria ao patrimônio (IPTU), à renda (IR) e aos serviços (ISS) dessas entidades. Assim, o II e o IPI não incidem sobre o patrimônio ou a renda. Mas o STF firmou o entendimento de que a imunidade referida abrange os impostos incidentes sobre a importação de bens, recebidos a título de doação, para uso exclusivo e desenvolvimento das atividades fins da Associação Torre de Vigia ${ }^{13}$.

Em outro caso prático, a Associação Torre de Vigia ajuizou ação cautelar, com pedido de medida liminar, e requereu a concessão de efeito suspensivo ao agravo de instrumento interposto contra a decisão do Vice-Presidente do Tribunal Regional Federal (TRF) da $3^{\text {a }}$ Região, que não admitiu o recurso extraordinário interposto em face de acórdão prolatado em mandado de segurança preventivo, em que se requereu o reconhecimento da imunidade prevista no artigo 150, VI, c. Neste caso, o juiz de $1^{\text {a }}$ instância reconheceu o direito pleiteado, mas o Tribunal o negou e ainda quis impedir a subida do recurso inadmitido ${ }^{14}$.

O STF ressaltou que, em situações excepcionais, em que estão presentes a plausibilidade jurídica do pedido e o perigo de dano irreparável ou de difícil reparação, o Tribunal poderá deferir a medida cautelar ainda que o RE não tenha sido admitido. O STF, em

13 BRASIL. Supremo Tribunal Federal. Agravo Regimental no Agravo de Instrumento no 378.454-2/SP. Relator: Min. Maurício Corrêa. Julgamento: 15/10/2002. Publicado DJ 29/11/2002. Brasília: Supremo Tribunal Federal, 2002. Disponível em: <http://redir.stf.jus.br/paginadorpub/paginador.jsp?docTP=AC\&docID=306274> Acesso em: 09 set. 2013.

14 BRASIL. Supremo Tribunal Federal. Referendo em Medida Cautelar em Ação Cautelar no 2.547/SP. Relator: Min. Joaquim Barbosa. Julgamento: 14/09/2010. Publicado DJ 08/10/2010. Brasília: Supremo Tribunal Federal, 2010. Disponível em: $<$ http://redir.stf.jus.br/paginadorpub/paginador.jsp?docTP=AC\&docID=615159> Acesso em: 09 set. 2013. 




outras decisões, já reconheceu o direito à imunidade da Requerente, e ressaltou que a decisão do TRF da $3^{\text {a }}$ Região, que descaracterizou o caráter assistencial e beneficente da atividade desempenhada à luz de preceitos religiosos, contraria a jurisprudência do STF.

Este caso é uma prova de que a questão, que parece pacífica, ainda é objeto de contestação em tribunais regionais ou estaduais. Portanto, ainda é um assunto apropriado para discussão sobre liberdade religiosa no campo fiscal, afinal, o direito à imunidade tributária, ainda que esteja consagrado há muitos anos, ainda demanda por efetivo respeito.

O STF nem sempre tem se posicionado pela concessão da proteção da imunidade tributária religiosa em todos os casos. Em relação à Maçonaria, o Tribunal, por maioria de votos, não reconheceu que a mesma se tratava de religião e, consequentemente, não conferiu às suas lojas o direito à imunidade tributária por não considerar seus locais de reunião como templos. O Ministro Marco Aurélio foi voto vencido. Não participaram do julgamento o Ministro Luiz Fux e a Ministra Rosa Weber15.

O Relator, Ministro Ricardo Lewandowski, argumentou que o Recorrente, o Grande Oriente do Rio Grande do Sul (que figurou como Representante da Maçonaria), não era um “culto na acepção técnica do termo”, por ser uma associação fechada, não aberta ao público, que não professa qualquer religião, apenas uma filosofia de vida de aperfeiçoamento moral, intelectual e social do homem e da humanidade, e considerou paradoxal que as mulheres não sejam admitidas, nem os homens que não exerçam uma profissão que lhes assegure meio de subsistência, e nem os analfabetos.

O Relator, citando o Recorrente, observou que há, dentro da maçonaria, discussão interna sobre ela ser ou não uma religião, alguns afirmando ser uma "religião das religiões", sempre atrelada a outras religiões, desde a Antiguidade, acreditando no "Grande Arquiteto do Universo", e também sustentando que cada um deve ter suas próprias convicções religiosas. "Não é religião com teologia, mas adota templos", conforme informação no site do recorrente, transcrita pelo Relator do recurso.

15 BRASIL. Supremo Tribunal Federal. Recurso Extraordinário no 562.351/RS. Relator: Min. Ricardo Lewandowski. Julgamento: 04/09/2012. Publicado DJ 14/12/2012. Brasília: Supremo Tribunal Federal, 2012. Disponível em: <http:www.stf.jus.br> Acesso em: 09 fev. 2015. 




É de interesse que a Procuradoria-Geral da República opinou pelo conhecimento parcial do recurso, reconhecendo aos seus templos a imunidade prevista no artigo 150, inciso VI, alínea $b$, da CF, ainda que não se reconhecesse a Maçonaria (no caso, o Grande Oriente do Rio Grande do Sul) como religião. Porém, o Relator do RE não deu provimento ao recurso interposto pelo representante jurídico da Maçonaria.

O Ministro Marco Aurélio, voto vencido, considerou que, através de "uma visão alargada da referência a 'templo', contida na alínea 'b' do inciso III do artigo 150” da CF, o templo maçom é merecedor da imunidade tributária. Adorar ou homenagear a divindade, como faz a maçonaria, é "culto" na acepção constitucional. Ele ressalta que, "Com a substituição da soberania do rei pela soberania do povo, as imunidades assumiram a posição de trincheiras em favor de certas liberdades públicas e valores políticos importantes à comunidade... como manifestações de um propósito maior”. Ele relembrou o famoso dizer do Justice Marshall, que "um poder ilimitado de tributar implica, necessariamente, um poder de destruir". Acentuou que o STF tem sustentado, em diversos julgados, uma interpretação ampla das imunidades, como o reconhecimento do direito aos álbuns de figurinhas, aos filmes e papéis fotográficos utilizados na fabricação de livros, e da imunidade de imóveis alugados a terceiros, pertencentes a instituições de assistência social.

O Ministro Marco Aurélio considerou a maçonaria uma "corrente religiosa", com "práticas ritualísticas", "no interior de um conceito mais abrangente de religiosidade" e onde há "uma profissão de fé em valores e princípios comuns, inclusive em uma entidade de caráter sobrenatural". Ele defende "um conceito mais largo de religião", inclusive pelo fato de a própria CF consagrar o pluralismo como valor básico brasileiro (artigo $1^{\circ}, \mathrm{V}$ ), repudiando uma definição ortodoxa de religião. $\mathrm{O}$ fato de a maçonaria não aceitar vários tipos de pessoas não é motivo para negar-lhe a imunidade.

Conforme já comentado em capítulo anterior, para que se configure o caráter religioso de um grupo para os fins da imunidade de impostos aos "templos de qualquer culto", não é necessário que se tenha uma crença definida, seja em Deus ou em alguma forma de poder sobrenatural, mas apenas se estão presentes as características de uma fé religiosa. Porém, conforme já exemplificado, o STF não reconheceu o direito à imunidade para a Maçonaria. 


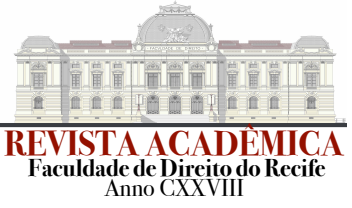

\section{ESTUDO DE CASO NO DIREITO COMPARADO}

A segunda metade da década de 1990 foi difícil para a liberdade religiosa na França. Em 1999, a situação atingiu um ponto crítico com a publicação do Relatório da Comissão Parlamentar de Inquérito (CPI) que investigou as atividades de várias "seitas" que tiveram seu caráter religioso desqualificado. Uma delas foi chamada de "grande seita" e sofreu diversos ataques: a religião das Testemunhas de Jeová.

A partir de agora será feita uma descrição dos pontos mais relevantes do Relatório para o caso, o que também preparará o leitor para a análise do julgamento do Recurso apresentado pela associação religiosa à Corte Europeia dos Direitos Humanos $(\mathrm{CEDH})$, que pôs um fim à discriminação tributária contra as Testemunhas de Jeová na França16.

O Relatório aponta que as Testemunhas de Jeová utilizam o trabalho de porta em porta como método de pregação e que seriam obrigadas a realizar um número mínimo de horas de pregação por mês, e de distribuir publicações, com exigência de relatório dessas atividades, além da formação regular de pregadores e missionários. É de se notar que o Relatório, por várias vezes, utilizou a discriminatória e pejorativa expressão "seita jeovista".

O Relatório acusou também que as Testemunhas seriam lembradas nos seus Salões do Reino da importância do dinheiro para a organização. Suas publicações defenderiam o altruísmo, muitas vezes com referências bíblicas à generosidade. A CPI reprovou que as Testemunhas, ao oferecerem suas publicações de casa em casa, digam que elas são gratuitas, mas que o morador, se quiser, pode fazer um donativo, visto que haveria aí uma "técnica de venda" - ao receber um presente, a pessoa se sente responsável a fazer um donativo. Este método também evidenciaria o interesse fiscal em disfarçar como doações o que poderia ser venda de produtos ou serviços, o que "prejudicaria" a arrecadação de impostos.

16 Os parágrafos que resumirão o Relatório serão baseados nas informações da seguinte referência: FRANÇA. Rapport fait au nom de la comission d'enquête sur la situation financiere, patrimoniale et fiscal des sects. Paris: Assembleia Nacional Francesa, 1999. Disponível em: <http://www.assemblee-nationale.fr/dossiers/sectes/ r1687p2.asp> Acesso em 24 ago. 2013. 


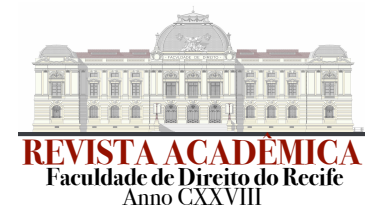

Tais publicações, segundo o Relatório, deixaram de ter preço a partir de uma decisão da Suprema Corte dos EUA em 1990, o que levaria à tributação dos rendimentos das mesmas. $\mathrm{Na}$ França, o preço de 2 francos, que era tradicionalmente mencionado para as revistas, desapareceu em 1991. Segundo o Relatório, as doações facultativas em troca das publicações teriam se tornado superiores ao que se arrecadava quando se estipulava um preço. A auditoria fiscal realizada, porém, foi incapaz de estabelecer a natureza lucrativa do negócio e de recolher o corpo de prova exigido por lei, o que incluiu a falta de preços visíveis.

Quanto às doações de Testemunhas de Jeová, a CPI identificou um suposto segundo fenômeno de evasão fiscal. Criticam-se os empréstimos feitos por pessoas físicas à Associação na condição de posterior devolução em caso de necessidade. A importância de determinados empréstimos sugeriria uma forma de contornar a impossibilidade legal de receber doações e legados.

As Testemunhas de Jeová tinham investido em impressão industrial, incluindo instalações de impressão, instalações de armazenamento e equipamentos de transporte. Seria a "seita" (dentre outras "seitas" citadas no relatório) com o maior interesse para investimentos imobiliários. Esse interesse reflete um desejo de afirmar a presença da organização em todo o país através de milhares de Salões do Reino que surgiram em toda a França. A Organização religiosa tinha vários edifícios no Aisne e na Normandia, e, especialmente, apartamentos em grande número em Boulogne-Billancourt para a acomodação dos membros que trabalham na gráfica e na sede nacional. A organização religiosa vendeu sua antiga sede em 17 de novembro de 1998 por 8,1 milhões de francos. De 1993 a 1998, as vendas totalizaram uma receita de trinta milhões de francos. Elas foram acompanhados pela construção em Louviers de novas instalações, um complexo administrativo e alojamentos. $\mathrm{O}$ grupo tinha também um outro local da cidade, com instalações e grandes oficinas (lavanderia, costura e outras funções). Os edifícios administrativos e residenciais estavam espalhados por 4,5 hectares, enquanto que os estabelecimentos chamados de "comerciais" e de armazenamento representavam uma área de 19,5 mil metros quadrados.

A Associação das Testemunhas de Jeová apresentou recurso à CEDH em 24 de fevereiro de 2005, nos termos do artigo 34 da Convenção Europeia para a Proteção dos 


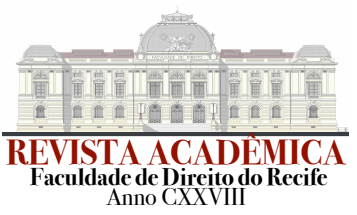

Direitos do Homem e das Liberdades Fundamentais ("a Convenção"). A requerente alegou, em especial, que a tributação dos livros doados a que ficou sujeita infringiu o direito de divulgar e exercer sua religião, garantido pelo artigo $9^{\circ}$ da Convenção ${ }^{17}$.

A Corte considerou que a rotulação das Testemunhas de Jeová como movimento "sectário", e as medidas tomadas contra movimentos qualificados como "seitas" levaram à marginalização das mesmas em toda a França. O Tribunal, por unanimidade, decidiu contra a França, que foi considerada violadora do direito da recorrente de difundir e exercer sua liberdade de religião, garantido pelo artigo $9^{\circ}$ da Convenção, que estabelece que toda pessoa tem direito à liberdade de pensamento, consciência e religião, o que inclui a liberdade de mudar de religião ou crença e a liberdade de manifestar essa religião ou crença, individual ou coletivamente, em público ou privado, na adoração, ensino, prática e observância.

O acórdão considerou que a Associação provou que sua sede administrativa é essencial para as atividades religiosas das Testemunhas de Jeová na França, pois fornece suporte espiritual para as mesmas. Além disso, quanto aos apartamentos comprados para a sede, ficou provado que os membros da comunidade religiosa dependiam dessas moradias para prestarem serviço de vida religiosa consagrada de caráter não empregatício. O recorrente se referiu a um acórdão do Tribunal Administrativo de Paris em 28 de março de 2007, que reconheceu a natureza religiosa das atividades dos membros do lar de Betel e que esta não é de natureza profissional. Assim, ao cobrar o imposto controvertido e exorbitante, o Estado francês violou o direito de adoração, e se tal tributação fosse confirmada, isso resultaria na venda da sede, resultando na perda de um local de adoração.

Também foi esclarecido na Decisão que a prática coletiva da fé religiosa tinha necessidade de contar com recursos materiais e que estes eram geralmente provenientes dos donativos. Tais doações eram de natureza religiosa e representavam o principal recurso da Associação, que segundo a Corte, correspondia a $86,47 \%$ do total de recursos. O tributo levaria inevitavelmente à venda do imóvel, que já estava hipotecado para isso. O Estado

17 Os parágrafos que resumirão o Acórdão serão baseados nas informações da seguinte referência: EUROPA. Corte Europeia de Direitos Humanos. Caso da Association Les Temoins de Jehovah v. France (Aplicação $\mathbf{n}^{\mathbf{0}}$ 8916/05). Julgamento: 30/06/2011. Estrasburgo, França: Corte Europeia de Direitos Humanos, 2011. Disponível em: <http://hudoc.echr.coe.int/sites/eng/pages/search.aspx\#\{"dmdocnumber":["887473"],"itemid": ["001-105386"] \}> Acesso 24 ago. 2013. 


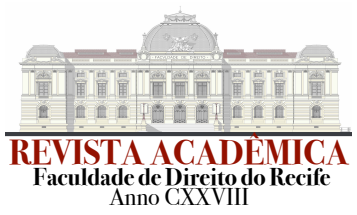

interferiu no campo da liberdade religiosa pela tributação punitiva motivada pelo desejo de suprimir as atividades das minorias religiosas inseridas na lista negra das "seitas".

O Tribunal observou que, salvo em casos muito excepcionais, o direito à liberdade de religião, garantida pela Convenção, exclui qualquer poder discricionário por parte do Estado sobre a legitimidade das crenças religiosas ou dos seus meios de expressão. Observou ainda que os donativos voluntários feitos pelas pessoas que adquiriam publicações religiosas eram uma importante fonte de financiamento para uma associação, seja religiosa ou antirreligiosa.

O Tribunal pontuou que o risco de congelamento das contas bancárias e da apreensão de bens era prejudicial para o funcionamento das atividades religiosas. A recusa em reconhecer uma organização religiosa, a ameaça de dissolução da mesma e o uso de linguagem depreciativa, são todos exemplos de violação do direito garantido pelo artigo $9^{\circ}$ da Convenção na sua dimensão externa e coletiva, e também dos direitos individuais dos membros que têm relação de pertencimento para com a religião.

A Corte não aceitou a alegação do Governo de que tal cobrança fiscal não teria efeito sobre a liberdade de religião sob o pretexto de que seus membros ficariam livres para praticar sua religião como entendessem. O objetivo perseguido pela medida não era legítimo, visto que visava a repressão da sua atividade. A medida foi desproporcional, pois o montante do imposto representava mais de $102 \%$ de seus recursos durante o período. Também não era necessária porque foi arbitrariamente determinada, sem nunca ter sido imposta antes ou depois do período controvertido. Não foi aceito o argumento de que a cobrança da dívida fiscal não causaria o desaparecimento das Testemunhas de Jeová na França, em vista do fato das associações locais, cada uma com personalidade jurídica própria e com "significativos" recursos, ainda existiriam mesmo que a sede religiosa nacional não mais existisse, e que, dada a extensão das atividades das Testemunhas de Jeová em todo o mundo, se o exercício das atividades da religião na França ficasse comprometido, associações religiosas estrangeiras não deixariam de tomar medidas para ajudar a Associação na França. O Tribunal considerou violado o artigo $9^{\circ}$ da Convenção. Como o governo francês não recorreu da decisão, o trânsito em julgado ocorreu em 2011. 




A CEDH tem um importante papel de proteção contra o abuso da soberania dos Estados da Europa. Tal soberania não pode ser absoluta porque tem como limite a dignidade da pessoa humana e das coletividades. Os tribunais continentais de direitos humanos são importantíssimos para a efetivação dos direitos fundamentais. No caso em apreço, a CEDH garantiu em favor da Associação das Testemunhas de Jeová na França o que é chamado pelo Direito Constitucional Brasileiro de Direito à Imunidade Tributária das atividades religiosas.

\section{CONCLUSÕES}

$\mathrm{O}$ alcance do instituto jurídico da imunidade constitucional tributária das instituições religiosas no Brasil foi examinado, com as seguintes tomadas de posições: a) a imunidade é objetiva porque o Estado não deve julgar quais conteúdos serão considerados bons ou ruins em matéria de religião; b) a imunidade aos impostos não se refere somente às edificações e é reforçada pela imunidade dos livros, jornais e periódicos e do papel destinado à impressão de publicações religiosas, e; c) o objetivo primordial da imunidade das instituições religiosas é proteger a liberdade de pensamento e de palavra.

Quanto aos casos selecionados da jurisprudência brasileira, ficaram evidenciadas as seguintes conclusões: a) a imunidade tributária não pode ser suprimida por emenda constitucional porque é uma cláusula pétrea; b) o direito à imunidade se estende para terrenos e imóveis alugados de propriedade da instituição religiosa; c) a imunidade tributária não é o mesmo que subvenção estatal porque o Estado não aporta recursos para as instituições religiosas; d) não se deve restringir o direito através de critérios de classificação dos impostos adotados por normas infraconstitucionais, e; e) a imunidade protege toda a infraestrutura erguida e preparada para a atividade da instituição.

O caso prático da discriminação tributária contra as Testemunhas de Jeová na França evidenciou que a exigência de tributos e multas praticada pelo Estado francês contra a Associação foi desproporcional. Observou-se que, desde o Relatório da Comissão Parlamentar de Inquérito, publicado em 1999, até o julgamento do Recurso perante a Corte 




Europeia dos Direitos Humanos, em 2011, passaram-se cerca de doze anos, período suficiente para demonstrar que a falta de respeito ao direito à imunidade tributária da instituição religiosa não constituiu em mera perda de privilégio fiscal, mas sim, em perda de dignidade, porque estimulou o preconceito contra os seus membros através de um tratamento desigual perante outras religiões socialmente mais prestigiadas.

A medida não foi adequada porque não havia nenhuma finalidade social relevante para a imposição de tal carga tributária. Não era necessária visto que levou ao sacrifício de liberdades fundamentais e promoveu a marginalização do grupo. Não atendeu também à proporcionalidade em sentido estrito porque não ocorreu a atividade de balanceamento entre o meio adotado pela autoridade (já que houve efetiva ausência de interesse público que justificasse a tributação), com a limitação de direito sofrida pela associação religiosa, que teve violado o seu direito à liberdade de praticar e de difundir a sua fé religiosa.

A imunidade tributária, assim, é importante para efetivar o pleno exercício da liberdade religiosa, pois, com ela, se evita a tributação da exteriorização das ideias religiosas, ou, em outras palavras, se evita a tributação do pensamento. A imunidade aos impostos serve, portanto, para não permitir que se realize política de censura fiscal contra entidades religiosas.

\section{REFERENCIAS}

ANDRADE FILHO, Edmar Oliveira. Imunidades tributárias na Constituição Federal. In Marcelo Magalhães Peixoto \& Cristiano Carvalho Coordenadores. Imunidade Tributária. São Paulo: MP Editora, 2005.

Infrações e sanções tributárias. São Paulo: Dialética, 2003

BALEEIRO, Aliomar. Limitações constitucionais ao poder de tributar. [Atualização Misabel Abreu Machado Derzi] 7ª ed. Rio de Janeiro: Forense, 1997.

BARRETO, Aires F. ISS na constituição e na lei. $3^{\text {a }}$ ed. São Paulo: Dialética, 2009.

BORGES, José Souto Maior. Lançamento Tributário. 2a ed. São Paulo: Malheiros, 1999.

- Relação entre tributos e direitos fundamentais. In Octavio Campos Fischer Coordenador. Tributos e Direitos Fundamentais. São Paulo: Dialética, 2004.

. Teoria Geral da Isenção Tributária. 3 ${ }^{\mathrm{a}}$ ed. São Paulo: Malheiros, 2001. 


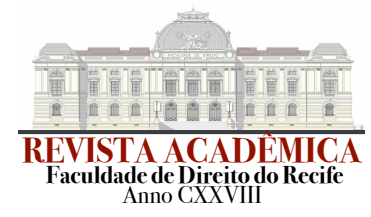

BRASIL. Ministério da Fazenda - Câmara Superior de Recursos Fiscais. Processo $\mathbf{n}^{\mathbf{0}}$ 10830.004351/2008-36. Relatora: Ana Clarissa Masuko dos Santos Araújo. Julgamento: 24/10/2013. Brasília: Câmara Superior de Recursos Fiscais, 2013. Disponível em: <http:// www.carf.fazenda.gov.br> Acesso em 09 fev. 2015.

Supremo Tribunal Federal. Agravo Regimental no Agravo de Instrumento $\mathbf{n}^{0}$ 740.563/SP. Relator: Min. Luiz Fux. Julgamento: 02/04/2013. Publicado DJ ?/?/?. Brasília: Supremo Tribunal Federal, 2013. Disponível em: <http://redir.stf.jus.br/paginadorpub/ paginador.jsp?docTP=TP\&docID=3688046> Acesso em: 09 set. 2013.

Supremo Tribunal Federal. Agravo Regimental no Agravo de Instrumento $\mathbf{n}^{\circ}$ 805.722/SP. Relator: Min. Rosa Weber. Julgamento: 26/02/2013. Publicado DJ ?/?/?. Brasília: Supremo Tribunal Federal, 2013. Disponível em: <http://redir.stf.jus.br/paginadorpub/ paginador.jsp?docTP=TP\&docID=3495941> Acesso em: 09 set. 2013.

. Supremo Tribunal Federal. Agravo Regimental no Recurso Extraordinário no 225.778-9/SP. Relator: Min. Carlos Velloso. Julgamento: 16/09/2003. Publicado DJ 10/10/2003. Brasília: Supremo Tribunal Federal, 2003. Disponível em: <http://redir.stf.jus.br/ paginadorpub/paginador.jsp?docTP=AC\&docID=332044> Acesso em: 09 set. 2013.

. Supremo Tribunal Federal. Agravo Regimental no Agravo de Instrumento $\mathbf{n}^{\circ}$ 378.454-2/SP. Relator: Min. Maurício Corrêa. Julgamento: 15/10/2002. Publicado DJ 29/11/2002. Brasília: Supremo Tribunal Federal, 2002. Disponível em: $<$ http://redir.stf.jus.br/ paginadorpub/paginador.jsp?docTP=AC\&docID=306274> Acesso em: 09 set. 2013.

Supremo Tribunal Federal. Agravo Regimental no Recurso Extraordinário com Agravo no 658.080/SP. Relator: Min. Luiz Fux. Julgamento: 13/12/2011. Publicado DJ 15/02/2012. Brasília: Supremo Tribunal Federal, 2012. Disponível em: $<$ http://redir.stf.jus.br/ paginadorpub/paginador.jsp?docTP=TP\&docID=1738528> Acesso em: 09 set. 2013.

Supremo Tribunal Federal. Agravo Regimental no Recurso Extraordinário com Agravo no 694.453/DF. Relator: Min. Ricardo Lewandowski. Julgamento: 25/06/2013. Publicado DJ ?/?/?. Brasília: Supremo Tribunal Federal, 2013. Disponível em: <http:// redir.stf.jus.br/paginadorpub/paginador.jsp?docTP=TP\&docID=4307503> Acesso em: 09 set. 2013.

Supremo Tribunal Federal. Ação Direita de Inconstitucionalidade no 939-7/DF. Relator: Min. Sydnei Sanches. Julgamento: 15/12/1993. Publicado DJ 18/03/1994. Brasília: Supremo Tribunal Federal, 1994. Disponível em: <http://www.stf.jus.br> Acesso em 15 out. 2014.

. Supremo Tribunal Federal. Recurso Extraordinário no 21.826/DF. Relator: Min. A. M. Ribeiro da Costa. Julgamento: 02/07/1953. Publicado DJ 30/12/1953. Brasília: Supremo Tribunal Federal, 1953. Disponível em: <http://redir.stf.jus.br/paginadorpub/ paginador.jsp?doc TP=AC\&docID=123183> Acesso em: 19 jun. 2014.

. Supremo Tribunal Federal. Recurso Extraordinário no 221.395-8/SP. Relator: Min. Marco Aurélio. Julgamento: 08/02/2000. Publicado DJ 12/05/2000. Brasília: Supremo Tribunal Federal, 2000. Disponível em: <http://redir.stf.jus.br/paginadorpub/paginador.jsp? docTP=AC\&docID=249570> Acesso em: 09 set. 2013.

Supremo Tribunal Federal. Recurso Extraordinário no 325.822-2/SP. Relator: Min. Ilmar Galvão. Relator para Acórdão: Min. Gilmar Mendes. Julgamento: 18/12/2002. 


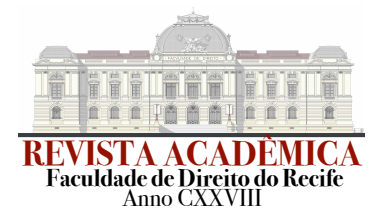

Publicado DJ 15/05/2004. Brasília: Supremo Tribunal Federal, 2004. Disponível em: <http:// redir.stf.jus.br/paginadorpub/paginador.jsp?docTP $=\mathrm{AC} \&$ docID $=260872>$ Acesso em: 09 set. 2013.

Supremo Tribunal Federal. Recurso Extraordinário n 562.351/RS. Relator: Min. Ricardo Lewandowski. Julgamento: 04/09/2012. Publicado DJ 14/12/2012. Brasília: Supremo Tribunal Federal, 2012. Disponível em: <http:www.stf.jus.br $>$ Acesso em: 09 fev. 2015.

Supremo Tribunal Federal. Recurso Extraordinário n⿳ 578.562-9/BA. Relator: Min. Eros Grau. Julgamento: 21/05/2008. Publicado DJ 11/09/2008. Brasília: Supremo Tribunal Federal, 2008. Disponível em: <http://redir.stf.jus.br/paginadorpub/paginador.jsp? docTP=AC\&docID=547393 > Acesso em: 09 set. 2013.

Supremo Tribunal Federal. Referendo em Medida Cautelar em Ação Cautelar $\mathbf{n}^{\mathbf{0}}$ 2.547/SP. Relator: Min. Joaquim Barbosa. Julgamento: 14/09/2010. Publicado DJ 08/10/2010. Brasília: Supremo Tribunal Federal, 2010. Disponível em: $<$ http://redir.stf.jus.br/ paginadorpub/paginador.jsp?docTP=AC\&docID=615159> Acesso em: 09 set. 2013.

CARNEIRO, Cláudio. Curso de direito financeiro e tributário. V. 1. $2^{\mathrm{a}}$ ed. Rio de Janeiro: Lumen Juris, 2010.

CARRAZA, Roque Antonio. A imunidade tributária dos templos de qualquer culto (art. 150, VI, $b$, da CF) - questões conexas. In Elizabeth Nazar Carraza Coordenador \& Daniel Moreti Organizador. Imunidades Tributárias. Rio de Janeiro: Elsevier, 2012.

CARVAlHO, Paulo de Barros. Curso de Direito Tributário. $12^{\mathrm{a}}$ ed. São Paulo: Saraiva, 1999.

EUROPA. Corte Europeia de Direitos Humanos. Caso da Association Les Temoins de Jehovah v. France (Aplicação no 8916/05). Julgamento: 30/06/2011. Estrasburgo, França: Corte Europeia de Direitos Humanos, 2011. Disponível em: <http://hudoc.echr.coe.int/sites/ eng/pages/search.aspx\#\{"dmdocnumber":["887473"],"itemid":["001-105386"]\}> Acesso 24 ago. 2013.

FRANÇA. Rapport fait au nom de la comission d'enquête sur la situation financiere, patrimoniale et fiscal des sects. Paris: Assembleia Nacional Francesa, 1999. Disponível em: $<$ http://www.assemblee-nationale.fr/dossiers/sectes/r1687p2.asp> Acesso em 24 ago. 2013.

HARADA, Kiyoshi. Direito financeiro e tributário. 13ª ed. São Paulo: Atlas, 2004.

KFOURI JR., Anis. Curso de Direito Tributário. São Paulo: Saraiva, 2010.

MACHADO, Schubert de Farias. Imunidade do livro. In Hugo de Brito Machado Coordenador. Imunidade tributária do livro eletrônico. $2^{\mathrm{a}}$ ed. São Paulo: Atlas, 2003.

TORRES, Ricardo Lobo. Tratado de Direito Constitucional Financeiro e Tributário - os direitos humanos e a tributação: imunidades e isonomia. $3^{\mathrm{a}}$ ed. rev. atual. Rio de Janeiro: Renovar, 2005. 




VERGUEIRO, Guilherme von Müller Lessa. Teoria constitucional da imunidade dos templos religiosos. In Marcelo Magalhães Peixoto \& Cristiano Carvalho Coordenadores. Imunidade Tributária. São Paulo: MP Editora, 2005.

VIEIRA, Oscar Vilhena. Direitos Fundamentais: uma leitura da jurisprudência do STF. São Paulo: Malheiros, 2006.

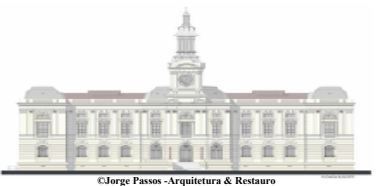

